\title{
PEMANFAATAN AGREGAT ALAMI DAN AGREGAT BATU PECAH SEBAGAI MATERIAL PERKERASAN PADA CAMPURAN ASPAL BETON
}

\author{
Bulgis, Rani Bastari Alkam \\ Staf pengajar Program Studi Teknik Sipil Fakultas Teknik Universitas Muslim Indonesia Jl. Urip \\ Sumoharjo KM. 05 Makassar. Email: bulgisbul@yahoo.com ; ranibastari@gmail.com
}

\begin{abstract}
Abstrak
Pada umumnya, konstruksi perkerasan lentur di Indonesia menggunakan agregat batu pecah yang dihasilkan melalui industri pemecah batu karena memiliki permukaan kasar dan bersudut sehingga memiiki daya lekat yang sangat baik terhadap aspal. Namun karena biaya yang besar dalam proses pengolahan dan pengangkutannya ke lokasi proyek, terkadang ditemukan pemanfaatan agregat alami yang memenuhi persyaratan untuk digunakan sebagai material agregat pada perkerasan. Dengan pertimbangan ini, penulis merasa perlu menguji dan menganalisis pengaruh keberadaan agregat alami dalam campuran aspal beton. Penelitian ini mengkaji pengaruh variasi kadar agregat alami terhadap kinerja campuran aspal beton dan menentukan kadar agregat alami yang dapat menghasilkan kinerja campuran aspal beton yang optimum. Metode penelitian ini berbasis eksperimen di Laboratorium Rekayasa Jalan Jurusan Sipil FT- UMI. Komponen pengujian utama adalah pengujian karakteristik campuran aspal beton dengan menggunakan material perkerasan berupa agregat alami, agregat batu pecah, dan atau kombinasi keduanya. Jenis pengujian laboratorium yang dilakukan adalah pemeriksaan properti material yang dilanjutkan dengan pengujian Marshall untuk memperoleh nilai kadar aspal optimum yang akan digunakan sebagai kadar aspal tetap pada pengujian inti yaitu pengujian Marshall pada komposisi campuran dengan variasi penambahan agregat alami. Berdasarkan hasil pengujian diketahui bahwa keberadaan agregat alami dalam campuran aspal beton mempengaruhi kinerja campuran dimana diperoleh kadar agregat alami yang mampu menghasilkan kinerja campuran yang optimum sebesar 10\%-50\% terhadap total berat agregat kasar.
\end{abstract}

Kata Kunci: Agregat Alami, Kinerja Campuran, Variasi Campuran, Aspal beton.

\section{PENDAHULUAN}

\section{I.1 Latar Belakang}

Pemilihan material perkerasan jalan yang tepat sesuai dengan karakteristik daerah adalah hal penting dalam pencapaian konsistensi kualitas perkerasan jalan sesuai dengan umur layan yang direncanakan. Pada perkerasan lentur dengan lapisan permukaan aspal beton, salah satu material yang berperan penting adalah agregat. Agregat merupakan butir-butir batu pecah, kerikil, pasir, atau mineral lain, baik yang berasal dari alam maupun bahan buatan yang berbentuk mineral padat berupa ukuran besar maupun kecil atau fragmen-fragmen (Sukirman, 2003).

Agregat memiliki beberapa peranan penting pada campuran aspal beton diantaranya sebagai penyumbang kekuatan struktural terbesar pada campuran, mengurangi susut perkerasan, dan mempengaruhi kualitas perkerasan. Berdasarkan proses pengolahannya, agregat digolongkan menjadi dua jenis yaitu agregat alam dan agregat buatan. Pada umumnya, konstruksi perkerasan lentur di Indonesia menggunakan agregat buatan atau batu pecah yang dihasilkan melalui industri pemecah batu yang memiliki permukaan kasar dan bersudut sehingga memiiki daya lekat yang sangat baik terhadap aspal. Selain itu, rongga antar agregat yang terjadi relatif lebih kecil sehingga dapat membentuk ikatan yang baik antar agregat. 
Agregat alami merupakan agregat yang berbentuk bulat dan memiliki permukaan yang relatif lebih licin dibandingkan dengan agregat buatan karena agregat ini mengalami pengikisan oleh air. Partikel agregat yang bulat saling bersentuhan dengan luas bidang kontak kecil sehingga menghasilkan interlocking yang lebih kecil. Agregat ini juga memiliki daya lekat yang kurang baik terhadap aspal karena memiliki permukaan yang cenderung lebih halus dan licin. Selain itu, rongga yang dihasilkan oleh agregat ini sangatlah besar karena memiliki bentuk yang relatif bulat dan tidak memiliki sudut seperti agregat buatan.

Dengan kelebihan yang dimiliki oleh agregat buatan jika dibandingkan dengan agregat alami, maka penggunaan agregat buatan pada campuran aspal beton merupakan langkah tepat untuk memperoleh kondisi lapisan perkerasan yang baik. Namun realita yang sering dijumpai di lapangan adalah dibutuhkan sumber daya yang sangat tinggi untuk mewujudkan penggunaan agregat buatan sebagai material pada campuran aspal beton secara utuh. Hal ini disebabkan karena biaya yang besar dalam proses pengolahan dan pengangkutan ke lokasi proyek. Di samping itu, terkadang ditemukan agregat alam yang masih mempunyai permukaan yang tidak rata (bulat) atau masih seperti bentuk semula dan memenuhi persyaratan untuk digunakan sebagai material agregat pada perkerasan (Syahputra, 2013).

Dengan pertimbangan ini, maka penulis merasa perlu menguji dan menganalisis pengaruh keberadaan agregat alami dalam campuran aspal beton sehingga diperoleh acuan yang toleran mengenai kadar pemanfaatan agregat alami dalam material perkerasan agar tujuan utama untuk mewujudkan lapisan perkerasan dengan karakteristik yang mantap dapat tetap tercapai. Atas dasar itulah, maka penulis melakukan penelitian mengenai Pemanfaatan Agregat Alami dan Agregat Batu Pecah sebagai Material Perkerasan pada Campuran Aspal Beton.

\section{I.2 Rumusan Masalah}

Bertitik tolak dari latar belakang yang telah dipaparkan sebelumnya, maka dapat dirumuskan beberapa permasalahan yang akan dikaji dalam penelitian ini yaitu:
1. Bagaimanakah pengaruh variasi kadar agregat alami dalam pemanfaatan sebagai material perkerasan terhadap kinerja campuran aspal beton?

2. Berapakah kadar agregat alami yang dapat menghasilkan kinerja campuran aspal beton yang optimum?

\section{I.3 Tujuan Penelitian:}

Secara umum, tujuan pelaksanaan penelitian ini adalah untuk mengkaji pemanfaatan agregat alami dan agregat batu pecah sebagai material perkerasan pada campuran aspal beton.

Secara khusus, untuk mencapai tujuan umum tersebut maka dibuat sub tujuan yang merupakan rincian tujuan dari penelitian ini yaitu:

1. Melakukan kajian pengaruh variasi kadar agregat alami dalam pemanfaatan sebagai material perkerasan terhadap kinerja campuran aspal beton.

2. Mengetahui kadar agregat alami yang dapat menghasilkan kinerja campuran aspal beton yang optimum.

\section{I.4 Ruang Lingkup Penelitian}

Mengacu pada tujuan penelitian, maka ditetapkan ruang lingkup penelitian untuk mencapai tujuan tersebut yaitu:

1. Jenis campuran yang digunakan adalah campuran Laston dengan menggunakan gradasi AC-WC

2. Agregat kasar (batu pecah), Agregat alami dan Agregat halus (pasir dan abu batu) yang digunakan berasal dari Enrekang Sedangkan Aspal yang digunakan adalah Aspal Pertamina pen 60/70.

3. Variasi penambahan kadar agregat alami pada campuran dilakukan dengan interval penambahan per $10 \%$ berdasarkan proporsi berat agregat kasar dalam campuran dengan menggunakan Kadar Aspal Optimum.

4. Pengukuran kinerja campuran aspal beton pada penelitian ini dilakukan dengan metode Marshall Test.

\subsection{Manfaat Penelitian}

Luaran dari hasil penelitian ini diharapkan dapat memberikan manfaat bagi berbagai pihak baik dalam aspek praktis maupun teoritis.

Untuk aspek praktis, penelitian ini diharapkan dapat menjadi acuan bagi pihak perencana dan

PUEESI PEMANFAATAN AGREGAT ALAMI DAN AGREGAT BATU PECAH SEBAGAI MATERIAL PERKERASAN PADA CAMPURAN ASPAL BETON 
pelaksana konstruksi khususnya konstruksi jalan raya dalam menentukan komposisi penyusun material perkerasan yang dapat menghasilkan efisiensi dan kualitas perkerasan jalan raya yang optimal.

Selain itu, penelitian ini diharapkan dapat memberikan manfaat teoritis yaitu sebagai sumbangan pemikiran untuk memajukan konsep ilmu pengetahuan khususnya di bidang ketekniksipilan dan pembangunan infrastruktur serta dapat menjadi referensi bagi mahasiswa teknik sipil dan peneliti berikutnya pada bidang yang berkaitan.

\section{STUDI PUSTAKA}

Agregat atau batuan merupakan komponen utama dari lapisan perkerasan jalan dengan proporsi $90-95 \%$ dari keseluruhan campuran berdasarkan presentase volume. Dengan demikian daya dukung, keawetan dan mutu perkerasan jalan ditentukan dari sifat agregat dan hasil campuran agregat dengan material lain. Agregat dapat dibedakan berdasarkan kelompok proses pengolahan dan ukuran butirnya yaitu agregat kasar, agregat halus, dan filler.

Fungsi dari agregat kasar dalam campuran aspal beton adalah sebagai penyokong stabilitas dan perlawanan gesekan yang terjadi pada lapisan perkerasan. Secara garis besar, agregat kasar digolongkan menjadi dua jenis, yaitu agregat buatan dan agregat alami. Agregat buatan atau batu pecah berasal dari agregat alami terbentuk dengan adanya campur tangan manusia dengan cara diolah terebih dahulu menggunakan alat pemecah batu. Sedangkan agregat alami merupakan agregat yang bentuknya alami, terbentuk berdasarkan aliran air sungai dan degradasi, Agregat alami yang berasal dari tempat terbuka disebut pitrun, sedangkan yang berasal dari tempat tertutup disebut bankrun.

Agregat kasar untuk campuran beraspal harus bersih, kuat, kering, awet, bersudut, bebas dari kotoran lempung dan material asing lainnya serta mempunyai tekstur permukaan yang kasar dan tidak bulat agar dapat memberikan sifat interlocking yang baik dengan material lainnya. Tingginya kandungan agregat kasar menjadikan lapis perkerasan lebih permeabel. Hal ini menyebabkan rongga udara meningkat dan menurunnya daya lekat bitumen, maka terjadi pengelupasan aspal dari batuan.
Partikel agregat dibedakan menjadi beberapa bentuk yaitu bulat (rounded), lonjong (elongated), kubus (cubical), pipih (flaky), tak beraturan (irregular), dan bersudut. Agregat alami didominasi oleh agregat berbentuk bulat yang saling bersentuhan dengan luas bidang kontak kecil sehingga menghasilkan interlocking yang lebih kecil dan mudah tergelincir. (Nemas, 2014).

Selain memberikan sifat ketahanan terhadap gelincir (skid resistance) pada permukaan perkerasan, tekstur permukaan agregat (baik mikro maupun makro) juga merupakan faktor lain yang menentukan kekuatan, workabilitas dan durabilitas campuran beton. Ukuran susunan agregat tergantung dari kekerasan, ukuran molekul, tekstur buatan, dan besarnya gaya yang bekerja pada permukaan butiran. Semakin kasar tekstur permukaan agregat maka konstruksi cenderung lebih stabil dibandingkan dengan permukaan halus.

Indonesia memiliki temperatur yang panas dengan kelembaban yang tinggi.sehingga pada batuannya terjadi pelapukan oleh cuaca. Agregat di Indonesia terdiri dari batuan muda secara geologis, misalnya basalts, dolomit, andesit, porfirit, tuff, abu. Batuan yang lebih dalam misalnya granit dan batuan maritim hasil sedimentasi, misalnya sandstone limestone, marlstone. Meskipun diayak terlebih dulu dan mungkin juga disiram sebelum diangkut, variasi masih mungkin terjadi.

Tujuan utama pengolahan agregat adalah untuk menghasilkan agregat dengan mutu tinggi dan biaya yang rendah. Pengolahan agregat alam meliputi penggalian (excavating), pengangkutan (hauling), pencucian, pemecahan (crushing), dan penentuan ukuran. Akan tetapi, pengolahan agregat tidak terbatas hanya pada usaha-usaha tersebut, tetapi dimulai juga dari penggalian dan diakhiri dengan penimbunan dan penyerahan agregat di lapangan.

Pada waktu penggalian, bahan-bahan yang akan menambah berat seperti lempung dan lanau sedapat mungkin harus disingkirkan terlebih dahulu. Penggalian bahan yang keras dapat dilakukan dengan peledakan (blasting). Setelah digali, agregat diangkut dengan kereta api, truk, atau ban berjalan (beltcoonveyor) ke tempat pengolahan agregat. Proses selanjutnya adalah memperkecil ukuran agregat dengan menggunakan pemecah batu. Untuk menentukan

PUEERI PEMANFAATAN AGREGAT ALAMI DAN AGREGAT BATU PECAH SEBAGAI MATERIAL PERKERASAN PADA CAMPURAN ASPAL BETON 
ukuran dari agregat, agaregat kasar disaring menggunakan saringan bergetar, sedangkan agregat halus disaring dengan saringan hidrolik. Dalam proses penyaringan, sekitar $70 \%$ dari bahan yang disaring harus lolos sehingga efisiensi serta kapasitas yang tinggi dapat dicapai.

Agregat harus disimpan sebaik mungkin untuk menjaga mutu yang disyaratkan, mencegah segregasi dan untuk memelihara gradasi dan kadar air agar agregat siap untuk digunakan. Agregat harus ditempatkan pada tempat yang terlindungi dari sinar matahari, permukaan yang bersih, dan bila dianggap perlu harus ditempatkan sedemikian hingga memudahkan pemeriksaan setiap waktu. Kondisi agregat harus dijaga terhadap kadar air, suhu, gradasi dan lain-lain agar tetap/konstan selama penyimpanan hingga dibawa ke tempat pencampuran.

Beberapa penelitian terdahulu mengkaji mengenai karakteristik agregat pada campuran aspal beton. Berikut adalah uraian penelitian terdahulu yang memiliki relevansi terhadap penelitian ini:

Profesor Teknik Sipil dan Lingkungan University of Massachusetts Dartmouth, Dr Walaa Mogawer melakukan penelitian tentang hot mix aspal yang mengandung agregat daur ulang. Penelitian ini dirancang untuk mengevaluasi kinerja campuran beraspal dengan agregat daur ulang untuk mengidentifikasi sifat material dan pengolahan yang diperlukan untuk menghasilkan campuran dengan kelelahan terendah dan sifat retak yang setara atau lebih baik dari campuran pada umumnya.

Di Indonesia, penelitian yang relevan telah dilakukan oleh Bagus Teguh Setiawan dari Universitas Negeri Yogyakarta, pada Juni 2012. Penelitian yang dilakukan bertujuan untuk mengetahui pengaruh keausan dan porositas agregat kasar daur ulang terhadap penurunan kuat tekan beton yang dihasilkan hingga tiga kali pengulangan, serta membandingkan kuat tekan beton daur ulang antara agregat dari sungai Opak dengan agregat hasil pengolahan.

Hasil penelitian menunjukkan bahwa:

1. Kuat tekan beton yang dihasilkan dari agregat daur ulang semakin menurun dalam setiap pengulangannya.
2. Hubungan keausan dan porositas agregat daur ulang dengan kuat tekan beton. Pada saat nilai keausan agregat turun sebesar $15.69 \%$ (R1), $43.03 \%$ (R2), $44.4 \%$ (R3), dengan nilai porositas agregat kasar turun sebanyak $58.28 \%$ (R1), $52.11 \%$ (R2), dan $47.28 \%$ (R3) kuat tekan betonnya menurun sebesar $1.25 \%$ (R1), $25.61 \%$ (R2), dan $82.56 \%$ (R3).

3. Kuat tekan beton daur ulang dengan agregat dari sungai Opak tidak lebih baik dari kuat tekan beton daur ulang dengan agregat dari hasil pengolahan.

\section{METODOLOGI PENELITIAN}

Secara umum, penelitian ini dilakukan dengan metode penelitian berbasis eksperimen di laboratorium. Komponen pengujian utama yang dititikberatkan pada penelitian ini, yaitu pengujian karakteristik campuran aspal beton dengan menggunakan material perkerasan berupa agregat alami, agregat batu pecah, dan atau kombinasi keduanya.

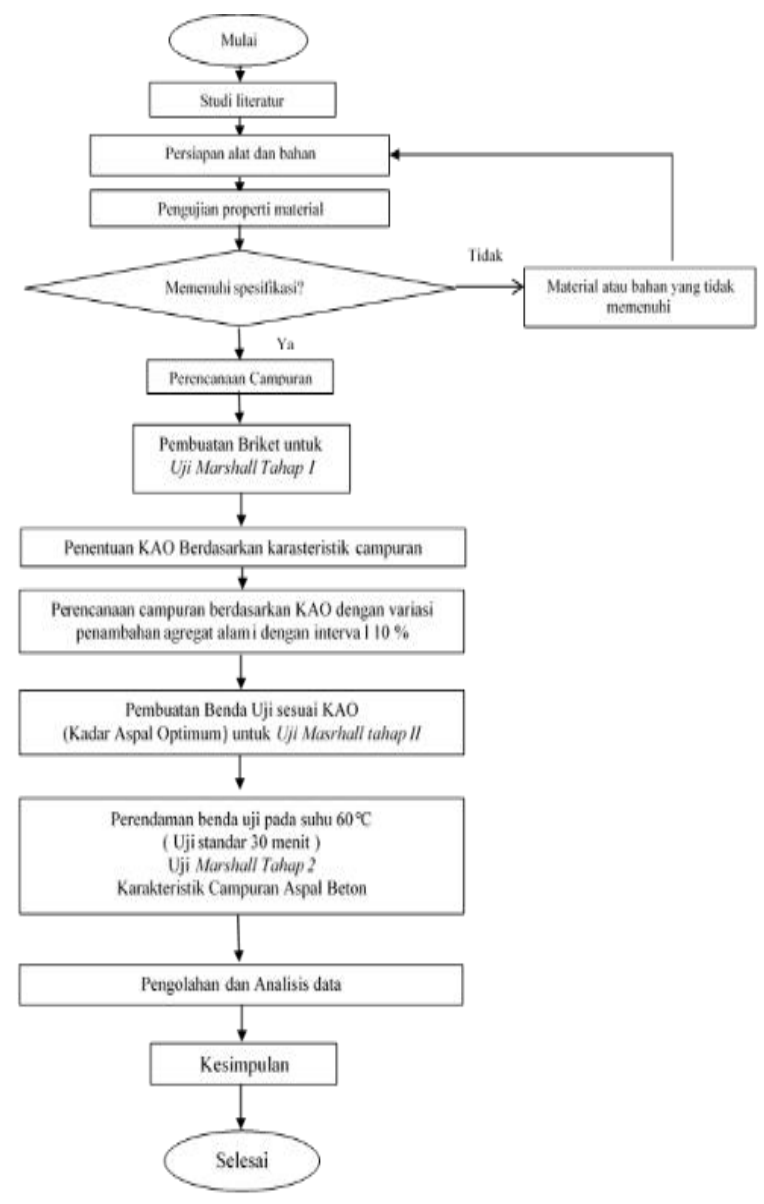

Gambar 1. Bagan Alir Penelitia

PUEERI PEMANFAATAN AGREGAT ALAMI DAN AGREGAT BATU PECAH SEBAGAI MATERIAL PERKERASAN PADA CAMPURAN ASPAL BETON 


\section{III.1 Studi Literatur}

Pada tahapan ini dilakukan kajian literatur yang berkaitan dengan topik penelitian untuk menunjang dan memperkuat kerangka berpikir yang akan dipergunakan sebagai dasar untuk menyusun metodologi penelitian. Tahapan ini juga bertujuan untuk menggali teori-teori dasar dan konsep yang telah ditemukan oleh para peneliti terdahulu sehingga orientasi dalam penelitian ini dapat dirumuskan dengan lebih terarah. Dalam kajian literatur penelitian ini difokuskan pada materi yang berhubungan dengan karakteristik agregat sebagai material perkerasan dalam campuran aspal beton.

\section{III.2 Tahap Persiapan Alat dan Bahan}

Langkah selanjutnya adalah menyiapkan peralatan dan material yang berkaitan dengan penelitian ini. Penelitian ini dilaksanakan di Laboratorium Teknik Jalan Raya Jurusan Sipil Fakultas Teknik UMI. Peralatan yang digunakan adalah segala peralatan yang tersedia di laboratorium yang berkaitan dengan pengujian properti material dan pegujian karakteristik campuran beraspal. Adapun material yang digunakan adalah agregat kasar yaitu agregat alami dan batu pecah, agregat halus (pasir dan abu batu), dan aspal pen 60/70.

\section{III.3 Tahap Pengumpulan Data}

Tahapan ini merupakan tahap pengujian di Laboratorium. Pengujian dimulai dengan pemeriksaan properti material baik pada agregat kasar, halus, maupun aspal dengan mengacu pada spesifikasi yang ada. Setelah hasil pengujian memenuhi spesifikasi maka pengujian dapat dilanjutkan namun jika hasil yang diperoleh belum memenuhi spesifikasi maka dilakukan pengujian ulang.

Langkah pengujian selanjutnya adalah penentuan komposisi campuran. Tahapan ini bertujuan untuk menentukan kadar aspal optimum dari variasi komposisi berat aspal yang diikuti dengan penyesuaian berat agregat baik agregat kasar maupun halus. Kadar aspal optimum diperoleh dari analisis karakteristik campuran beraspal dengan meninjau beberapa parameter hasil pengujian Marshall tahap I yaitu VIM, VMA, VFB, flow, stability, dan Marshall Queotient.

Kadar aspal optimum selanjutnya dijadikan sebagai kadar aspal untuk seluruh variasi agregat alami yang digunakan dalam penentuan komposisi campuran. Adapun variasi kadar agregat alami yang diuji adalah setiap interval $10 \%$ yang dikombinasikan dengan agregat batu pecah. Komposisi yang ada kemudian dicampur dalam bentuk briket dengan suhu pencampuran dan suhu pemadatan tertentu.

Pengujian Marshall tahap II dilakukan pada briket yang telah dibuat dan telah melalui proses perendaman sesuai dengan prosedur teknis yang ada. Pada pengujian marshall ini dilakukan pengumpulan data karakteristik campuran beraspal untuk setiap variasi. Data ini selanjutnya akan dikaji pada tahap selanjutnya.

Berikut ini adalah perhitungan jumlah sampel (briket) yang direncanakan akan diuji berdasarkan prosedur dan variasi yang digunakan dalam penelitian ini:

Tabel 1. Sampel Pengujian

\begin{tabular}{|c|c|c|c|c|c|c|c|c|c|c|c|}
\hline \multirow[t]{2}{*}{ Pengujian } & \multicolumn{5}{|c|}{ Variasi Kadar Aspal (\%) } & & & & & & \multirow{2}{*}{$\begin{array}{l}\text { Jumlah } \\
\text { Sampel }\end{array}$} \\
\hline & 4,5 & 5 & 5,5 & 6 & 6,5 & & & & & & \\
\hline $\begin{array}{c}\text { Penentuan Kadar } \\
\text { Aspal Optimum }\end{array}$ & 3 & 3 & 3 & 3 & 3 & & & & & & 15 \\
\hline \multirow[t]{2}{*}{ Pengujian } & \multicolumn{10}{|c|}{ Variasi Kadar Agregat Alami (\%) } & \multirow{2}{*}{$\begin{array}{l}\text { Jumlah } \\
\text { Sampel }\end{array}$} \\
\hline & 10 & 20 & 30 & 40 & 50 & 60 & 70 & 80 & 90 & 100 & \\
\hline $\begin{array}{c}\text { Pengujian Marshall } \\
\text { untuk beberapa } \\
\text { variasi kadar agregat } \\
\text { alami }\end{array}$ & 3 & 3 & 3 & 3 & 3 & 3 & 3 & 3 & 3 & 3 & 30 \\
\hline \multicolumn{11}{|c|}{ Total Jumlah Sampel } & 45 \\
\hline
\end{tabular}




\section{III.4 Tahap Analisis dan Interpretasi Data}

Pada tahapan ini dilakukan analisis secara grafis dan analitis untuk menentukan hubungan dan pengaruh dari setiap parameter berikut:

a. Analisis perbandingan karakteristik campuran yang dihasilkan dari campuran aspal beton menggunakan material agregat alami maupun agregat batu pecah. Analisis ini berdasarkan data pengujian karakteristik Marshall pada komposisi campuran tanpa agregat alami dan komposisi campuran tanpa agregat batu pecah.

b. Kajian pengaruh variasi kadar agregat alami sebagai material perkerasan terhadap kinerja campuran aspal beton. Tahap ini menganalisis performance campuran pada setiap kadar agregat alami.

c. Penentuan rekomendasi kadar agregat alami yang dapat menghasilkan kinerja campuran aspal beton yang optimum. Didasarkan pada komposisi campuran yang menunjukkan nilai parameter Marshall yang paling optimum jika dibandingkan dengan komposisi lainnya.

\section{III.5 Perumusan Kesimpulan dan Saran}

Hasil interpretasi data pada tahap sebelummya menjadi landasan dalam penyusunan kesimpulan sebagai jawaban dari rumusan masalah. Kesimpulan yang ditarik direncanakan mencakup pemberian rekomendasi terhadap interval kadar agregat alami yang masih dapat ditolerir mengacu pada data karekteristik campuran hasil pengujian.Selain itu, hasil ini menjadi acuan untuk memberikan saran terhadap penelitian berikutnya.

\section{ANALISIS DAN PEMBAHASAN}

\section{IV.1 Hasil Pengujian Marshall Test Untuk Penentuan Kadar Aspal Optimum}

Pengujian ini dilakukan untuk memperoleh nilai kadar aspal optimum (KAO) dan menentukan ketahanan (stabilitas) terhadap kelelehan plastis (flow) dari campuran aspal. Analisis karakteristik campuran beraspal diperoleh dengan meninjau beberapa parameter hasil pengujian Marshall yaitu VIM, VMA, VFB, flow, stability, density, dan Marshall Queotient. Dalam pelaksanaan pengujian Marshall ini digunakan lima variasi kadar aspal, yaitu $(4,5 \%$; $5 \% ; 5,5 \% ; 6 \%$; \& 6,5\%). Berdasarkan hasil pengujian diperoleh data sebagai berikut:

Tabel 2. Rekapitulasi Pengujian Marshall Campuran AC WC untuk Kadar Aspal Optimum (KAO)

\begin{tabular}{|c|c|c|c|c|c|c|c|c|}
\hline \multirow{2}{*}{ No } & \multirow{2}{*}{$\begin{array}{c}\text { Kadar } \\
\text { Aspal }\end{array}$} & Stabilitas & Flow & VIM & VMA & VFA & MQ & Density \\
\cline { 3 - 9 } & & $\begin{array}{c}\text { Min } \\
\mathbf{8 0 0 ~ K g}\end{array}$ & $\begin{array}{c}\mathbf{2 - 4} \\
\mathbf{m m}\end{array}$ & $\begin{array}{c}\text { Min } \\
\mathbf{3} \%\end{array}$ & $\begin{array}{c}\text { Min } \\
\mathbf{1 5} \%\end{array}$ & $\begin{array}{c}\text { Min } \\
\mathbf{6 5} \%\end{array}$ & $\begin{array}{c}\text { Min 250 } \\
(\mathbf{K g} / \mathbf{m m})\end{array}$ & $\begin{array}{c}\text { Min 2,2 } \\
\text { Kg/mm }\end{array}$ \\
\hline 1 & $4,5 \%$ & 890,82 & 2.25 & 5,976 & 14,612 & 59,106 & 394,67 & 2,439 \\
\hline 2 & $5 \%$ & 886,79 & 2,47 & 4,584 & 14,322 & 68,016 & 364,54 & 2,424 \\
\hline 3 & $5,5 \%$ & 1068,16 & 2.45 & 4,283 & 15,016 & 71,519 & 443,23 & 2,409 \\
\hline 4 & $6 \%$ & 1011,75 & 2.42 & 3,740 & 15,493 & 75,896 & 418,34 & 2,395 \\
\hline 5 & $6,5 \%$ & 947,25 & 3,10 & 3,723 & 16,425 & 77,342 & 310,46 & 2,381 \\
\hline
\end{tabular}




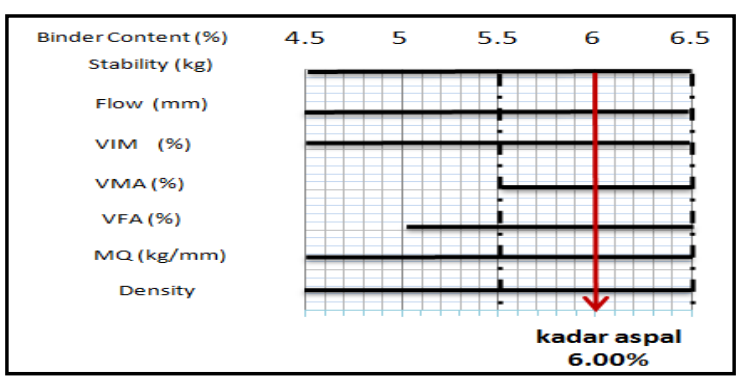

Gambar 2. Penentuan Kadar Aspal Optimum

Nilai yang diinput pada grafik di atas adalah kadar aspal yang memenuhi spesifikasi untuk setiap kadar aspal. Untuk menentukan kadar aspal optimum maka diambil nilai tengah dari batas atas dan batas bawah irisan kadar aspal dari setiap variasi sebagai berikut:

$$
\mathrm{KAO}=\frac{5,5+6,5}{2}=6 \%
$$

Dari grafik karakteristik campuran diatas diperoleh nilai kadar aspal terendah dan tertinggi yang memenuhi spesifikasi, yaitu batas minimum 5,5 \%, dan batas maksimum $6.5 \%$. Selanjutnya dari batas maksimum dan minimum tersebut diperoleh nilai tengah sebesar 6\%. Nilai tengah inilah yang menjadi kadar aspal optimum (KAO) yang akan digunakan pada perencanaan campuran AC-WC dengan variasi Agregat Alami $10 \%, 20 \%, 30 \%$ 40\%,50\%, 60\%,70\%, $80 \%, 90 \%$ dan $100 \%$.

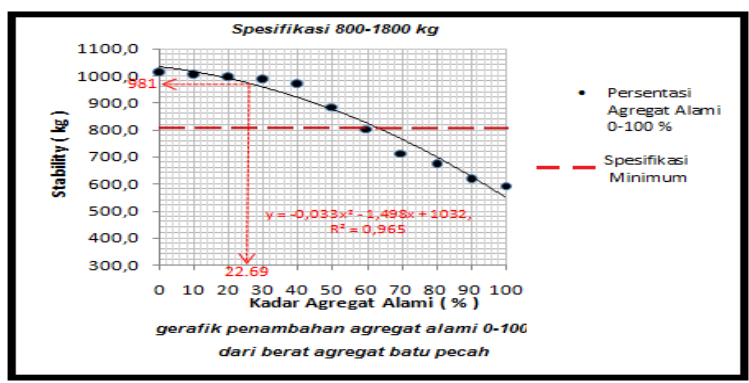

Gambar 3. Nilai stabilitas untuk setiap variasi kadar Agregat alami.

Nilai stabilitas menurun seiring dengan penambahan agregat alami. Untuk kadar agregat alami $10 \%$ - 50\% nilai stabilitas memenuhi spesifikasi sementara kadar agregat alami $60 \%$ $100 \%$ tidak memenuhi spesifikasi. Penggunaan kadar agregat alami yang berlebihan tidak baik, karena daya ikat dari lapisan aspal sudah tidak efektif untuk penguncian antar partikel, sehingga terjadi gesekan antar butir.

Nilai flow terus mengalami penurunan seiring dengan penambahan kadar agregat alami. Hal ini

\section{IV.2 Pengaruh Agregat Alami terhadap Karakteristik Campuran Beraspal}

Setelah diperoleh kadar aspal optimum selanjutnya dilakukan pengujian terhadap sampel aspal beton yang menggunakan komposisi kadar aspal optimum yang dikombinasikan dengan beberapa variasi prosentasi kadar agregat alami terhadap total agregat yang digunakan.

Pengujian dilakukan dengan mendefinisikan karekterisitk sifat-sifat Marshall yaitu Stabilitas, Flow, VIM, VMA, VFA, Marshall Questiont, dan Density. Hasil pengujian marshall campuran aspal beton dengan pemanfaatan Agregat Batu Pecah dan Agregat Alami adalah sebagai berikut:

\section{a. Stabilitas}

Stabilitas adalah kemampuan perkerasan jalan dalam menerima beban lalu lintas tanpa terjadi perubahan bentuk.

Berikut ini adalah grafik yang menujukkan nilai stabilitas dalam satuan $\mathrm{kg}$ akibat adanya penggunaan agregat alami dan agregat batu pecah dengan perbandingan $(0 / 100 \%, 10 / 90 \%$, $20 / 80 \%, 30 / 70 \%, 40 / 60 \%$, 50/50\%, 60/40\%, $70 / 30 \%, 80 / 20 \%, 90 / 10 \%, 100 / 0 \%)$ dari total berat agregat.

menggambarkan bahwa campuran menjadi lebih rentan mengalami deformasi akibat beban lalu lintas jika penggunaan kadar agregat alami semakin bertambah. Nilai flow untuk kadar $10 \%$ - 50\% memenuhi spesifikasi, sedangkan untuk kadar $60 \%$ - $100 \%$ sudah tidak memenuhi spesifikasi.

\section{b. Kelelehan (Flow)}

Nilai flow menyatakan besarnya deformasi yang terjadi pada suatu lapis perkerasan akibat beban lalu lintas. Suatu campuran dengan nilai flow tinggi akan cenderung lembek, sehingga mudah berubah bentuk jika menerima beban. Sebaliknya jika flow rendah maka campuran menjadi kaku dan mudah retak jika menerima beban yang melampaui daya dukungnya.

PUĖתI PEMANFAATAN AGREGAT ALAMI DAN AGREGAT BATU PECAH SEBAGAI MATERIAL PERKERASAN PADA CAMPURAN ASPAL BETON 


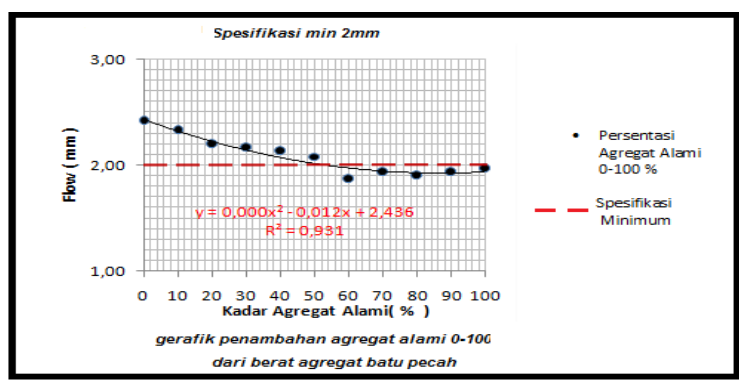

Gambar 4. Nilai Flow untuk setiap variasi kadar Agregat alami.

Nilai flow terus mengalami penurunan seiring dengan penambahan kadar agregat alami. Hal ini menggambarkan bahwa campuran menjadi lebih rentan mengalami deformasi akibat beban lalu lintas jika penggunaan kadar agregat alami semakin bertambah. Nilai flow untuk kadar $10 \%$ - 50\% memenuhi spesifikasi, sedangkan untuk kadar $60 \%$ - $100 \%$ sudah tidak memenuhi spesifikasi.

\section{c. Void in Mixture (VIM)}

Void In Mixture (VIM) adalah parameter yang menunjukkan volume rongga yang berisi udara dalam campuran aspal yang dinyatakan dalam $\%$ volume, berikut grafik VIM akibat adanya penggunaan agregat alami dan agregat batu pecah dengan perbandingan $(0 / 100 \%, 10 / 90 \%$, $20 / 80 \%, 30 / 70 \%, 40 / 60 \%, 50 / 50 \%, 60 / 40 \%$, $70 / 30 \%, 80 / 20 \%, 90 / 10 \%, 100 / 0 \%$ ) dari total berat agregat batu pecah.

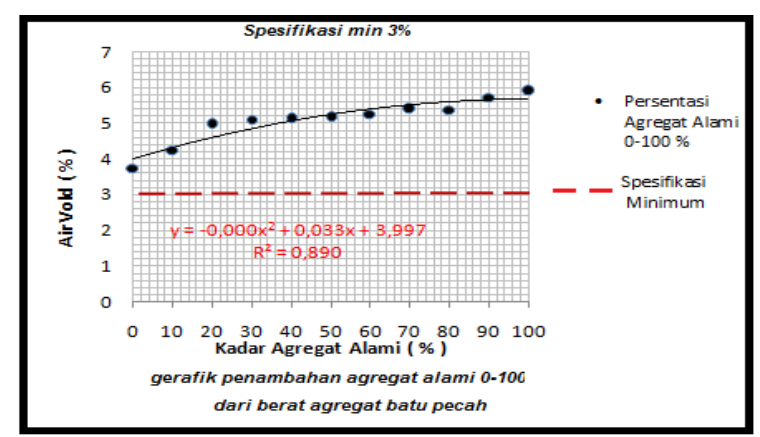

Gambar 5. Nilai VIM untuk setiap variasi kadar Agregat alami.

Nilai VIM semakin meningkat seiring dengan penambahan kadar agregat alami. Dengan semakin rendahnya nilai VIM maka semakin kecil pula rongga dalam campuran yang artinya campuran semakin baik. Seluruh variasi kadar Agregat Alami yang diujikan yaitu dari 0 hingga $100 \%$ memenuhi spesifikasi.

\section{d. Void in Mineral Aggregate (VMA)}

Voids in Mineral Aggregates (VMA) adalah volume rongga yang terdapat diantara butir-butir agregat dari suatu campuran beraspal yang telah dipadatkan, termasuk didalamnya rongga udara dan rongga yang berisi aspal efektif, dinyatakan dalam \% volume, berikut grafik VMA akibat adanya penggunaan agregat alami dan agregat batu pecah dengan perbandingan $(0 / 100 \%, 10 / 90 \%, 20 / 80 \%, 30 / 70 \%, 40 / 60 \%$, $50 / 50 \%, 60 / 40 \%, 70 / 30 \%, 80 / 20 \%, 90 / 10 \%$, $100 / 0 \%)$.

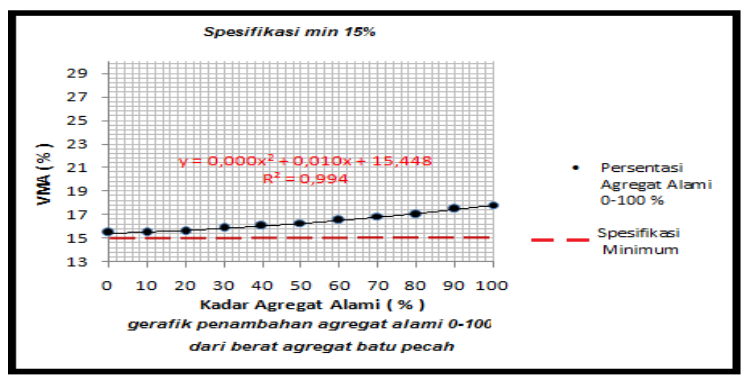

Gambar 6. Nilai VMA untuk setiap variasi kadar Agregat alami.

Nilai VMA semakin meningkat seiring dengan penambahan kadar agregat alami. Semakin besar penambahan kadar agregat alami menyebabkan besarnya rongga antar agregat pada campuran, hal ini disebabkan karena bentuk agregat alami yang cenderung bulat dan permukaannya licin sehingga daya ikat antar agergat lebih kecil jika dibandingkan dengan bentuk agregat batu pecah.

\section{e. Void filled with Asphalt (VFA)}

Void Filled with Asphalt (VFA) adalah bagian volume rongga dalam agregat yang terisi aspal yang dinyatakan dalam \% terhadap rongga antar butiran ageragat (VMA). Berikut grafik VFA akibat adanya penggunaan agregat alami dalam campuran aspal beton.

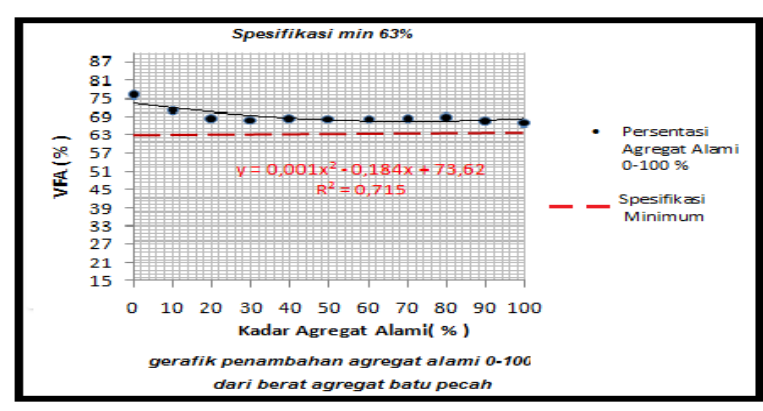

Gambar 7. Nilai VFA untuk setiap variasi kadar Agregat alami. 
Nilai VFA semakin menurun seiring dengan penambahan kadar agregat alami. Nilai VFA yang diperoleh dari penambahan agregat alami lebih rendah jika dibandingkan nilai VFA yang diperoleh dari penggunaan batu pecah, hal ini disebabkan karena penyerapan agregat alami terhadap aspal kurang baik sehingga jumlah aspal efektif yang mengisi rongga antar butir agregat pada penambahan Agregat Alami semakin rendah sehingga rongga udara pada campuran semakin besar.

\section{f. Kepadatan (Density)}

Density atau kepadatan adalah rasio antara berat benda uji kering dengan volume benda uji yang dipengaruhi oleh temperatur, komposisi, kadar bahan tambah, pemadatan, dan kadar aspal.

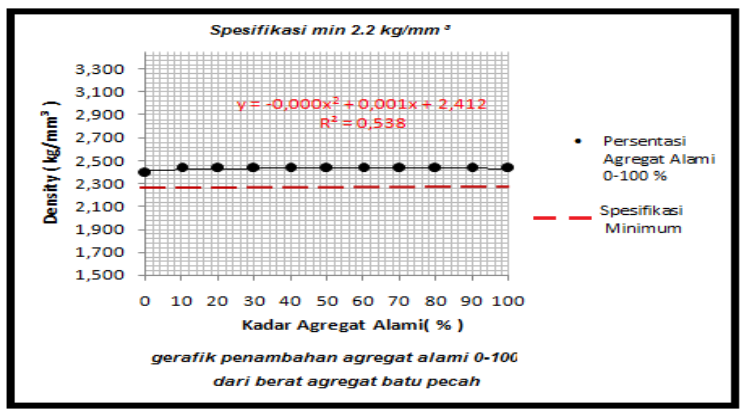

Gambar 8. Nilai Density untuk setiap variasi kadar Agregat alami.

Nilai Density yang diperoleh mengalami peningkatan seiring dengan penambahan kadar agregat alami. Peningkatan yang terjadi tidak signifikan. Meskipun begitu seluruh nilai density yang diperoleh untuk setiap kadar agregat alami memenuhi spesifisikasi yaitu minimal 2,2 gr/cm.

\section{g. Marshall Quotient}

Marshall Quetient adalah nilai perbandingan yang menunjukkan nilai kekuatan suatu campuran beraspal dalam menerima beban dalam $\mathrm{kg} / \mathrm{mm}$. Nilai MQ diperoleh dari perbandingan antara nilai stabilitas yang dikoreksi terhadap nilai kelelehan (flow).

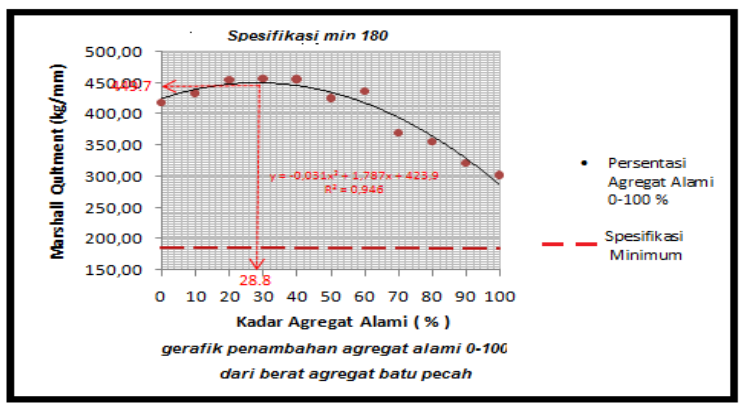

Gambar 9. Nilai Marshall Questiont untuk setiap variasi kadar Agregat alami.
Penambahan kadar Agregat Alami dapat meningkatkan nilai Marshal Quotient hingga batas maksimum yaitu $50 \%$, Kemudian nilai MQ pada Variasi kadar filler 60\% - 100\% kembali mengalami penurunan dikarenakan penggunaan kadar Agregat Alami yang berlebihan tidak baik karena daya lekat aspal sudah tidak efektif lagi.

\section{IV.3 Penentuan kadar agregat alami yang dapat menghasilkan kinerja campuran aspal beton yang optimum}

Untuk menentukan kadar agregat alami yang mampu menghasilkan kinerja campuran aspal beton yang optimum maka dilakukan evaluasi hasil pengujian Marshall terhadap karakteristik campuran aspal beton meliputi nilai stabilitas, flow, VIM, VMA, VFA, Density, dan Marshall Questiont yang ditunjukkan pada gambar berikut:

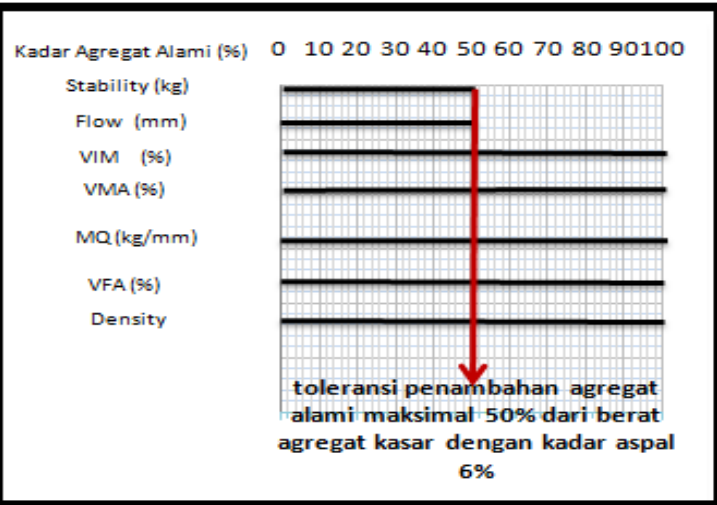

Gambar 10. Penentuan Toleransi kadar Agregat Alami

Berdasarkan gambar 10 terlihat bahwa toleransi penambahan agregat alami dari 10\% hingga 50\% terhadap berat total agregat kasar memenuhi spesifikasi untuk seluruh karakteristik campuran yang ditinjau sedangkan penambahan agregat Alami dari $60 \%$ sampai $100 \%$ tidak memenuhi spesifikasi untuk karakterisitk stabilitas dan flow. Oleh karena itu, jika ditinjau dari aspek karakteristik campuran aspal yang memenuhi batas yang disyaratkan maka kadar agregat alami sebesar 10 hingga 50\% merupakan interval kadar yang mampu menghasilkan kinerja campuran aspal beton yang optimum.

Dari hasil ini dapat diinterpretasikan bahwa persentase Campuran Aspal Pertamina pen 60/70 yang dikombinasikan dengan Agregat Alami sebesar $10 \%$ hingga 50\% serta agregat batu pecah, mampu bertahan terhadap kerusakan yang di sebabkan oleh beban lalu lintas.

PUËII PEMANFAATAN AGREGAT ALAMI DAN AGREGAT BATU PECAH SEBAGAI MATERIAL PERKERASAN PADA CAMPURAN ASPAL BETON 


\section{PENUTUP}

\section{V.1 Kesimpulan}

Berdasarkan hasil penelitian dan pembahasan di bab sebelumnya maka peneliti menarik kesimpulan sebagai berikut:

1. Variasi kadar agregat alami mempengaruhi kinerja campuran Aspal beton. Semakin besar kadar agregat alami yang digunakan memberikan pengaruh terhadap karakteristik campuran aspal beton sebagai berikut: terjadinya penurunan nilai stabilitas, penurunan nilai flow (kelelehan), peningkatan nilai VIM (rongga dalam campuran), peningkatan nilai VMA (rongga pada butir agregat), penurunan nilai VFA (rongga yang terisi aspal), peningkatan yang tidak signifikan pada nilai density (kepadatan campuran), dan peningkatan nilai Marshall Questiont pada kadar tertentu yang selanjutnya menurung seiring dengan penambahan kadar agregat alami.

2. Kadar agregat alami yang dapat menghasilkan kinerja campuran aspal beton yang optimum berada pada interval 10\% $50 \%$ terhadap total berat agregat kasar. Penentuan toleransi kadar agregat alami ini dilakukan berdasarkan evaluasi hasil pengujian Marshall terhadap karakteristik campuran aspal beton yang meliputi nilai stabilitas, flow, VIM, VMA, VFA, Density, dan Marshall Questiont.

\section{V.2 Saran}

Berdasarkan hasil penelitian yang diperoleh serta proses penelitian yang telah dilalui peneliti, diusulkan beberapa saran sebagai berikut :

1. Dapat dilakukan penelitian lanjutan untuk meneliti pemanfaatan agregat alami dengan menggunakan jenis aspal yang lebih bervariasi.

2. Penelitian ini diharapkan dapat lebih dikembangkan untuk penelitian selanjutnya dengan menggunakan bahan kimia yang dapat memberikan daya rekat aspal yang lebih kuat terhadap agregat alami.

3. Penelitian ini diharapkan dapat dikembangkan lebih lanjut untuk meneliti lebih mendalam pengaruh penambahan agregat alami terhadap pengaruh cuaca.

4. Penelitian ini diharapkan dapat menjadi referensi bagi pihak yang terkait khususnya di bidang perkerasan jalan.

\section{DAFTAR PUSTAKA}

Akzo, Nobel. 2003. Asphalt Applications. HeatStable Adhesion Promoter for Bituminous Binders.

Atkins, Harold N. 2003. Highway Materials, Soils, and Concretes fourth edition.Pearson Education Inc: Upper Saddle River, New Jersey.

Departemen Pekerjaan Umum. 2010. Spesifikasi Umum Bidang Jalan dan Jembatan, Badan Penelitian dan Pengembangan PU, Departemen Umum, Jakarta.

Departemen Pekerjaan Umum. 2010. Seksi 6.3 Spesifikasi Campuran Beraspal Panas ,Jakarta.

Huang, Y.H. 2004. Pavement Analysis and Design, Pearson Education, Inc., Upper Saddle River, New Jersey.

Nemas, Dian. 2014. Teknologi Bahan Bangunan Agregat. Jurnal.

Saodang, Hamirhan. 2005. Perancangan Perkerasan Jalan Raya. Nova, Bandung.

Sukirman, Silvia. 2003. Beton Aspal Campuran Pana. Granit, Jakarta.

Syahputra, Rio. 2013. Pengaruh Agregat Bentuk Bulat (ROUNDED AGGREGATE) terhadap Karakteristik Marshall Campuran Beton Aspal AC-WC Menggunakan Aspal Penetrasi 60/70 Sebagai Bahan Pengikat. Jurnal 